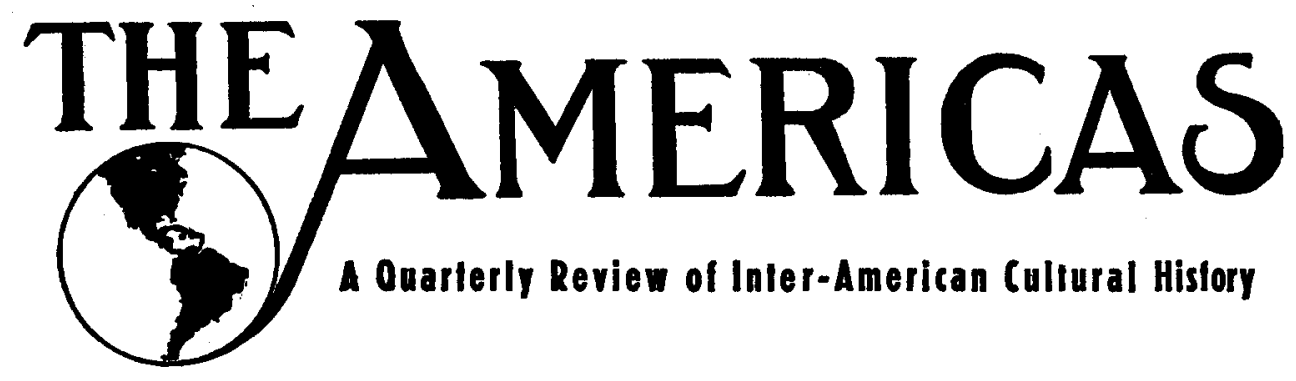

\title{
VOLUMe VII
}

JULY, 1950, THROUGH APRIL, 1951

Published Quarterly

by the

Academy of American Franciscan History

Washington, D. C.

1951 


\section{ARTICLES}

The Social Reforms of San Martín........ William H. Gray 3

The Church of San Francisco in Mexico City

Fidel de J. Chauvet 13

Salvatierra's Legacy to Lower California

Peter Masten Dunne 31

Viceroy Revillagigedo II as Vice-Patron of the Church

James $M$. Manfredini 51

Aspects of Navaho Life.................... Berard Haile 63

The International Colloquium on Luso-Brazilian Studies

Lewis Hanke 133

Notes for a Biography of Salvador Correia de Sá e Bena-

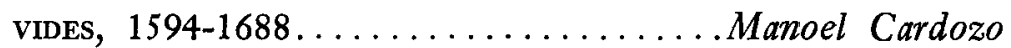

The Reluctant Revolutionist. A Study of the Political Ideas of Hipólito da Costa, 1774-1823 . . . . Janke Herrick 171

The Trial of the Ecclesiastics in the Inconfidencia Mineira Ernesto Ennes

Venerable Antonio Margil de Jesús, O.F.M. Friar of the Winged Feet, 1657-1726..............Paul V. Murray. 267

Versicle of PeAce ....................Gabriela Mistral 281

Fray Isidro Félix de Espinosa. Companton and Biographer of Margil ....................Michael B. McCloskey

The Missionary Influence of the College of Zacatecas Alberto María Carreño

José Vasconcelos .................... Ronald Hilton 395

Some Truths About Mexico.............Fanchón Royer 413

The Library of the Apostolic College of San Fernando, Mexico, in the Eighteenth and Nineteenth Centuries Maynard Geiger 425

John A. Zahm, C.S.C.: Scientist and Americanist Thomas F. O'Connor 435

Chile and Hispanic-American Solidarity, 1810-1830

Elliot A. Marcus 


\section{IN MEMORIAM}

Thomas F. O'Connor. . . . . . . . . . . . . . . . . 321

Livarius Oliger, O.F.M...............Eustace J. Smith 475

\section{DOCUMENTS}

Bishop Fleming's Visitation of Newfoundland, 1834-1835

(Ed.) Thomas F. O'Connor 73, 481

In Defense of the Maranhá Indians of Colonial Brazil

(Ed.) Luiza Fonseca 215

The Letters of Margil in the Archivo de la Recolección in Guatemala ................(Ed.) Lázaro Lamadrid 323

Two Margil Documents........ (Ed.) Michael B. McCloskey 356

\section{INTER-AMERICAN NOTES}

The International Colloquium on Luso-Brazilian Studies, Washington, D. C., October 18-21, 1950 .......... 221

Annual Convocation of the Academy of American Francis-

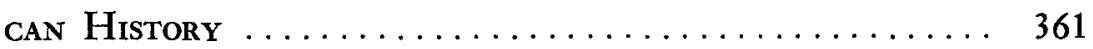

The Serra Award of the Americas Conferred upon Gabriela Mistral ........................... 363

The Committee on the Origins of the Independence Movement and Its Publications . . . . . . . . . . Roscoe R. Hill 501

Miscellaneous Notes ..................101, 231, 367

Book Reviews ...................105, 235, 373, 505 